\title{
Corrupting the Cyber-Commons: Social Media as a Tool of Autocratic Stability
}

\author{
Seva Gunitsky
}

\begin{abstract}
Non-democratic regimes have increasingly moved beyond merely suppressing online discourse, and are shifting toward proactively subverting and co-opting social media for their own purposes. Namely, social media is increasingly being used to undermine the opposition, to shape the contours of public discussion, and to cheaply gather information about falsified public preferences. Social media is thus becoming not merely an obstacle to autocratic rule but another potential tool of regime durability. I lay out four mechanisms that link social media co-optation to autocratic resilience: 1) counter-mobilization, 2) discourse framing, 3) preference divulgence, and 4) elite coordination. I then detail the recent use of these tactics in mixed and autocratic regimes, with a particular focus on Russia, China, and the Middle East. This rapid evolution of government social media strategies has critical consequences for the future of electoral democracy and state-society relations.
\end{abstract}

$T$ he use of social media in autocratic states, initially touted as a democratic panacea, has increasingly come to be seen as a mixed blessing for democracy activists. While it can be used for spreading anti-regime information and mobilizing collective action, governments have quickly learned to control and limit the use of social networks through a variety of sophisticated censorship tools.

Focusing only on the effects of censorship, however, ignores an insidious recent trend-the shift from social media suppression to social media co-option. Over the past few years, elites in autocratic and hybrid regimes have increasingly begun to subvert social media for their own purposes and employing it as a tool of regime stability. As a result, social media is being transformed from an engine of protest to another potential mechanism of regime resilience.

Namely, social media has enabled non-democratic incumbents to safely gather previously hidden or falsified information about public grievances, to increase the transparency of the performance of local officials, to bolster regime legitimacy by shaping public discourse, and to enhance the mobilization of their support base.

Seva Gunitsky is Assistant Professor of Political Science at the University of Toronto (seva1000@gmail.com). His work examines external influences on democratization, recently appearing in International Organization and International Theory. He thanks Ronald Deibert, Victor Falkenheim, Jeffrey Isaac, Daniel Alan Kennedy, Rebecca MacKinnon, and the anonymous Perspectives on Politics reviewers for helpful comments and suggestions.
As a result, autocrats have begun to move beyond strategies of "negative control" of the internet, in which regimes attempt to block, censor, and suppress the flow of communication, and toward strategies of proactive co-optation in which social media serves certain regime functions. The opposite of internet freedom, therefore, is not necessarily internet censorship but a deceptive blend of control, co-option, and manipulation.

The evolution of rigged elections in hybrid regimes offers an instructive parallel: while the spread of elections in the 1990s was expected to help consolidate democratic gains, their actual effect on democracy has been deeply ambiguous. Non-democracies have used unfair elections to increase their stability and durability-for instance, by reinforcing the regime's legitimacy or revealing the extent of its support among the population. ${ }^{1}$ Similarly, despite social media's potential for democratization, skillful autocrats have increasingly transformed it into a tool of regime entrenchment. I lay out four mechanisms that link social media co-option to autocratic regime durability: 1) countermobilization, 2) discourse framing, 3) preference divulgence, and 4) elite coordination. I then detail the recent use of these tactics in mixed and autocratic regimes, with a particular focus on Russia, China, and the Middle East.

First, just as rigged elections offer opportunities for highly visible propaganda and socialization campaigns, social media creates space for the management of public discourse that sidelines or discredits anti-regime sentiment, while at the same time mobilizing the regime's own supporters. The bolstering of legitimacy through social media occurs through two related mechanisms-discourse framing that shapes the perceptions of the public at large, and counter-mobilization of the regime's support base. 
Second, like flawed elections, social media acts as a reliable and relatively costless tool for gauging and pre-empting public grievances, which otherwise remain hidden or falsified, and in doing so prevents them from escalating into active protests. The informational role of social media also helps resolve the principal-agent problem inherent in coordinating the interests of central and local elites. Operating in an opaque institutional environment, local elites have incentives to misrepresent regime efficiency and popularity to central authorities, and social media offers a way to resolve this information asymmetry by allowing citizens to call attention to local problems. The informational role of social media thus also operates through two mechanisms-preference divulgence of public grievances and elite coordination within the governing apparatus.

These developments represent the latest phase in the relationship between non-democratic regimes and online technology. While the literature on social media has moved beyond the simplistic early debates between cyberskeptics and cyber-utopians, it continues to focus on the role of anti-regime protestors, and how social media impacts-or doesn't impact-their tactics, repertoires, and mobilization strategies. Autocratic governments, on the other hand, are analyzed mostly through the lens of their responses to unrest, focusing on regime strategies to censor and suppress social media. Yet it is the rapid evolution of proactive government strategies that portends some crucial consequences for the future of democratization.

Scholars of autocratic regimes have sometimes invoked the persistence of the "Dictator's Dilemma" - an ineluctable trade-off autocrats face when dealing with social media and online communication. ${ }^{2}$ Allowing the increased availability of such technology, according to this argument, is crucial for regimes desiring economic development and global integration, but also threatens their very existence by allowing unfettered flows of information. However, the co-option of social media by non-democratic regimes may offer a way out of this dilemma, allowing governments to reap the benefits of online technology without suffering its destabilizing costs.

Even more problematic is the prospect of social media as a potential substitute for unfair elections. After all, even elections heavily rigged in favor of the incumbent inevitably carry the threat of political unrest or even electoral defeat. Since 1946, fifty-one incumbent autocratic parties have lost rigged elections. ${ }^{3}$ Over the past decade flawed elections have served as focal points for the mobilization of opposition movements in the so-called Color Revolutions, leading to regime turnover in a number of post-Soviet states. Such defeats can occur even in countries where the ruling party has well-entrenched patronage networks, as in Indonesia in 1999 or Mexico in 2000.

Even when elections do not lead to protests or opposition victories, autocrats may not always be able to determine the credibility of the information revealed through elections. Citizens may view fraudulent elections as performance rituals that will not reflect actual political outcomes, foregoing the opportunity to voice their real preferences. Instead, they may opt for the riskless strategy of supporting the incumbent. Flawed elections, in other words, may perform poorly at revealing falsified preferences, particularly in cases where voters fear the possibility of persecution from the regime. Moreover, electoral manipulation at the local level may distort incoming information before it reaches the central elite, preventing them from properly gauging the extent of anti-regime sentiment. ${ }^{4}$

Despite their benefits, therefore, flawed elections are a sub-optimal solution for autocratic leaders. They can still threaten incumbent elites or fail to fulfill their ostensible functions of demonstrating regime legitimacy and revealing private information. Social media, on the other hand, can act as a reliable, low-risk, and relatively costless substitute for the functions served by rigged elections. While social media has made it easier for citizens to monitor and publicize electoral violations, it has also increased the costs to autocrats of holding such elections, while decreasing any benefits they may have gained from introducing them in the first place.

Clearly, social media cannot replace every function served by manipulated elections. It does not create new lines of patronage, allow competing elites to jostle for power, reveal the ability of local officials to mobilize votes, or produce spectacular pro-regime celebrations associated with elections in some competitive autocracies. But to the extent that it acts as a plausible substitute for mass suffrage, it may in some cases lower autocratic incentives to hold elections.

These developments have several implications for the future of democratization. First, active citizen participation in social media does not necessarily signal regime weakness, and may in fact enhance regime strength and adaptability. Second, democratization in hybrid and autocratic regimes may become stuck in a low-level equilibrium trap, as these regimes become responsive enough to subvert or pre-empt protests without having to undertake fundamental liberalizing reforms or loosen their monopoly over political control. Third, social media co-option may help regimes inoculate themselves from the reach of transnational social movements as well as domestic reformers, portending greater obstacles for the diffusion of protest tactics across borders. Fourth and more speculative, hybrid regimes may become increasingly less likely to use elections as a way of gathering information, revealing falsified preferences, coordinating elites, channeling grievances, and bolstering regime legitimacy. Closed autocracies, which have traditionally existed in a particularly information-scarce environment, may have fewer incentives to introduce elections in the future. 
A word on definitions: the term "social media" is related to, but not synonymous with, the more general notion of information and communication technology (ICT). Social media refers to a number of online tools that facilitate the creation and sharing of highly interactive and user-generated content. These include networking sites, bulletin board systems, chat rooms, micro-blogging and instant message services, as well as photo and video-sharing sites. Most importantly, social media is often (though not always) associated with inside-country networks. Much of the Western debate surrounding Chinese internet censorship, for instance, has revolved around "the Great Firewall of China," and the potential for cross-border flows of information to empower pro-democracy movements. Yet many of the most important social transformations associated with online technology involve social media sites run by Chinese companies and catering exclusively to Chinese citizens - in other words, networks operating inside the Great Firewall. ${ }^{5}$

Though transnational services like Facebook and Twitter remain important outlets for political expression, the less well-studied, country-specific social media outletsChina's WeChat or Russia's VKontakte-are rapidly becoming both a source of active citizen participation and a tool for non-democratic governments. Given the trend toward the increased territoriality of the internet-a trend bolstered by both state and corporate interests-these within-country networks are likely to only increase in importance over the near future. ${ }^{6}$ The political consequences of information flows across national borders are thus significantly different from the political consequencesboth good and bad-of information flows within in-country outlets, and it is the latter sort of media technology on which I focus here.

\section{From the Streets to the Palace}

Much of the early debate about the role of social media in democratization has been framed by two sides, the socalled cyber-optimists and cyber-skeptics. The former argue that online technology is a powerful new tool for mobilizing anti-regime dissent and facilitating democratization. Clay Shirky, for example, argues that the internet can lower the barriers to collective action by facilitating leaderless coordination. And Larry Diamond argues that the internet can function as a "liberation technology," allowing residents of closed societies to disseminate news and opinions, expose corruption, and mobilize protests. ${ }^{7}$

The skeptics, meanwhile, argue that online technology is either ineffective or marginal to the process of regime contestation, and is easily subject to government censorship and control. As Deibert et al. have argued, internet censorship techniques have continuously evolved, from filtering and surveillance to site shutdowns and network attacks. Moving beyond access denial, governments have begun to engage in more subtle methods of control like "just-in-time" filtering, and are now actively contesting both the flow of online information and the legitimacy of norms and rules surrounding cyberspace control. ${ }^{8}$ Moreover, decreasing the costs of participation may lead to widespread but ineffective political involvement, in which facile expressions of support replace costlier forms of physical protest. ${ }^{9}$

Moving beyond the early, term-defining debate between skeptics and utopians, much of the current literature on the role of social media has focused on the specific conditions under which anti-regime forces can employ social media to achieve their goals. Most observers fall somewhere into the cautious middle, conceding that social media can function as a tool of anti-regime mobilization while emphasizing its limits and unintended consequences. Shirky, for example, has since moderated his optimistic position, noting that the use of social media by protestors "does not have a single preordained outcome." ${ }^{10}$ As Marc Lynch concludes in his analysis of the Arab Spring, while "protestors effectively used social media in their struggles, it is surprisingly difficult to demonstrate rigorously that these new media directly caused any of the outcomes with which they have been associated." 11

While this debate is continuously evolving, it has also been limited by a near-exclusive focus on anti-regime protestors. The bulk of the discussion thus revolves around the extent to which social media can aid democratization, with the answers ranging from "a great deal" to "no impact." Authoritarian governments are portrayed as playing a reactive role, responding to protests by finding ways to control social media communication. With the exception of a few authors I will examine, the role of states is therefore examined largely in terms of how effectively they repress and disrupt social media. ${ }^{12}$

Yet this debate only captures half the story, and perhaps not even the most important half. Less examined is the proactive and anticipatory role played by incumbent elites. As Oates recently noted, while "there are studies of how states seek to control the internet, there is little discussion of how states actively use the internet to expand their communicative power." ${ }^{13}$ And as Aday et al. argue, "relatively little" is known about the "active use of new media by authoritarian governments." ${ }^{14}$ Sheena Greitens, for example, distinguishes between regime control, which includes the traditional tools of online repression, and regime activism, in which non-democratic governments embrace social media for their own purposes. As she notes, "contemporary discussions of authoritarian Internet regulation has tended to focus more on the dimension of control, perhaps because it is easier for scholars and pundits to observe. The dimensions of surveillance and activism, however, are equally important." ${ }^{15}$ My focus, therefore, is on the various ways in which social media is being supplanted to serve regime interests. 


\section{Bolstering Regime Legitimacy}

In closed and hybrid regimes, manipulated elections create opportunities for ostentatious propaganda campaigns that function along two parallel dimensions: the marshaling of domestic groups that traditionally serve as the government's support base, and the ritualistic affirmation of the regime aimed at all citizens more generally. ${ }^{16}$ Similarly, bolstering regime legitimacy through social media functions through the two related mechanisms of counter-mobilization of supporters and discourse framing of the larger national discourse.

First, in the face of potential online opposition, regimes can use the extensive reach of social networks to counter-mobilize their own base of support. Just as opposition leaders can use social media to lower barriers to collective action and mobilize protestors, regimes can also employ online technology to organize and rally their own domestic allies. These include not only groups that directly benefit from government patronage (such as military or business elites), but also regular citizens motivated by patriotism, ideology, or a general sense that the regime has earned their trust. Few regimes exist without some measure of public support or legitimacy, and this is especially true in mixed or hybrid regimes, which rely in part on the passive acquiescence or the active support of various groups to remain in power. Domestic support for the government in Russia or China, for instance, is not merely an illusory artifact of oppression, but reflects real popularity derived from economic performance, nationalism, or anti-Western ideology. Leaders in such regimes can thus draw upon social networks to maintain a connection with these supporters. "If the authorities do not like what is happening on the internet there is only one way of resisting," Putin said in 2011, suggesting that the internet should be used as a resource "to collect a larger amount of supporters." ${ }^{17}$

Second, beyond using social media to forge links with their supporters, incumbent rulers can employ it to disseminate propaganda in a more efficient way, and to shape online discourse in a more precise and adaptive manner. Propaganda via message framing goes beyond brute-force censoring to choreograph and channel the bounds of acceptable deliberation. Yongnian Zheng has argued, for example, that certain types of activism in China can actually reinforce regime legitimacy through careful management of online discourse. Online protest calling for the introduction of multi-party politics or independence for irredentist groups is quickly censored. At the same time, grievances calling for reforms or demands to address corruption-protest within the bounds of the established political framework-can be used by party moderates as ideological ammunition against communist hard-liners. ${ }^{18}$ Similarly, King, Pan, and Roberts have recently argued that Chinese authorities do not simply censor all anti-regime posts on social media, even those that express vitriolic anti-government sentiment. Instead, they focus on those posts that demonstrate potential for collective action, spur social mobilization, or fundamentally challenge the regime's legitimacy. ${ }^{19}$ At the same time, anti-regime posts that expose local corruption or ineffective policies serve as a basis for publicizing government responsiveness to local demands. ${ }^{20}$

Even a country as closed as North Korea has begun to widen the use of social technology, recently allowing a million of its citizens to possess cell phones. ${ }^{21}$ Yet this increased acceptance of internet technology "may simply be a call for making the old propaganda and information system more efficient." ${ }^{22}$ Online technology in North Korea can be used to increase foreign investment, decrease demand for illegal information sources, and widen the already-extensive reach of government surveillance and propaganda. (The country's cell-phone owners receive daily text messages praising the regime.) Thus the risks of expanding online access "may be more than offset by political benefits accrued to the regime," argues Greitens, while "controlled expansion may work in favor of the North Korean regime rather than to its detriment." ${ }^{23}$

The two strategies of discourse framing and countermobilization are closely linked and often reinforce each other. Regimes have frequently mobilized their supporters to shape the content of online conversations. Such assistance is particularly important in hybrid regimes like Russia, which do not engage in the direct blocking of websites and focus not on denying access but on "successfully competing with potential threats through effective counterinformation campaigns that overwhelm, discredit, or demoralize opponents." ${ }^{24}$ These include techniques like mobilizing regime supporters to disrupt planned rallies, plant false information, monitor opposition websites, and harass opposition members. Allegations of "web brigades," in which Russian commenters were paid to post pro-regime comments and discredit the opposition, first appeared over a decade ago. These organized groups were alleged to frequent popular prodemocracy forums to "shape the public consciousness" via distraction and disinformation. ${ }^{25}$

In 2012 the Russian newspaper Gazeta.ru reported that the Kremlin-sponsored youth group Nashi has spent hundreds of thousands of dollars to pay bloggers, journalists, and commenters to post pro-regime message on websites and social media outlets. According to hacked emails released by the Russian arm of Anonymous, Nashi had paid online posters to "dislike" anti-regime videos on YouTube and to leave pro-Putin comments on negative stories about the Russian president. ${ }^{26}$ "Their main problem is that they don't have real people who are ready to say something in support of them," opposition leader Alexey Navalny told the British newspaper The Guardian in response. "They don't have one person who supports 
them for free. So they pay." 27 Popular bloggers like Ilya Varlamov, according to the e-mails, had been paid 400,000 rubles (about \$12,000) merely for publishing two posts favorable to the regime- a charge that Varlamov later denied. ${ }^{28}$ In 2013 the Russian newspaper Novaya Gazeta reported that a "school for internet trolls," with apparent links to Nashi, has been set up on the outskirts of St. Petersburg. Its employees are expected to produce approximately a hundred posts per day, pouring scorn on the West and Russian opposition leaders like Navalny while praising Russia's culture and political leaders. ${ }^{29}$

Russian government control strategies thus "tend to be more subtle and sophisticated and designed to shape and affect when and how information is received by users, rather than denying access outright." ${ }^{30}$ Unable to employ the blunt instruments of censorship available in tightly controlled societies like China, the Russian government has adopted a strategy that Rebecca MacKinnon calls digital bonapartism, or using "populist rhetoric, combined with control over private enterprise and the legal system, to marginalize the opposition and manipulate public opinion much more subtly than in the old days." ${ }^{31}$ Prime Minister Dmitry Medvedev, for example, has seized upon social media as a way to project a more modern and populist image, conducting online chats and running a Twitter account with nearly 700,000 followers. Since 2010, Russian citizens have been able to use online tools to "participate" in meetings of the Presidential Commission for Modernization and Technological Development of Russia's Economy. A government-created forum, i-Russia. $\mathrm{ru}$, allows people to post comments with suggestions about current or proposed laws.

The co-option of social media has been aided by the Russian government's ongoing efforts to place social media sites under their indirect control. In January 2014, for example, the ownership of VKontakte was transferred to a pro-Putin oligarch after signs of harassment against its original founder. ${ }^{32}$ Such behind-the-scenes manipulation avoids the heavy-handedness of outright censorship while allowing the regime to indirectly shape the acceptable bounds of social media discourse. In sum, according to Fossato and Lloyd, the Russian internet is a platform "which the state uses increasingly successfully to consolidate its power and spread messages of stability and unity among the growing number of Russians regularly accessing websites and blogs." 33

Like Russia, the Chinese government has moved beyond blocking communications and toward proactively shaping the online conversation by hiring hundreds of thousands of online commentators to write posts that show the party in a positive light. ${ }^{34}$ This so-called "fifty cent party" (wumao dang), named after the payments its members receive for pro-regime posts, "patrols chat rooms and online forums, posting information favorable to the regime and chastising its critics. ${ }^{\text {"35 }}$ As a result, efforts to co-opt social media by Chinese authorities "are more decentralized, agile, and proactive than commonly portrayed, and they actively seek to involve the population in favorably shaping online content." ${ }^{36}$

Social media counter-mobilization and discourse framing strategies were also clearly on display in the Arab Spring. During the Egyptian protests in January 2011, for instance, the country's authorities ordered national cell phone carriers to send out mass SMS texts to mobilize proMubarak supporters against anti-regime demonstrators. At the start of the Syrian civil war, the government began to encourage pro-regime bloggers and hackers to use Facebook, YouTube, and other social media "to rally supporters and plan attacks" against anti-government activists and Western media, notes MacKinnon. In May 2011, an organization linked to the regime and calling itself the Syrian Electronic Army began to use Facebook to recruit supporters, "targeting the Facebook pages and accounts of government critics and activists with insults and progovernment messages." 37

During the 2011 protests in Bahrain, the regime used social media to track down protestors with the help of regime supporters. The government set up its own Facebook sites like "Together to Unmask the Shia Traitors," which encouraged Bahrainis to identify demonstrators via online photographs. The pictures were then marked off with a red checkmark as individuals were identified and arrested. ${ }^{38}$ As MacKinnon notes, shortly after the protests began, "progovernment bloggers, Facebook activists, and Twitter users popped up like mushrooms after a rainstorm, posting news and 'evidence' that the protesters were Shiite terrorists in league with Iran, and blaming them for the bloodshed." 39 In this way the government used social media to disseminate information, solicit evidence about the opposition, shape the public narrative about opposition leaders, and legitimate the government response to the protestors.

In shaping dominant narratives and mobilizing support, social media can help incumbents in guarding themselves not only from domestic unrest but also from external pressures for reform. During the Arab Spring, for example, both Russia and China employed social media to promote negative narratives of what they portrayed as Western-sponsored destabilization, and marshaled grassroots bloggers to encourage nationalist sentiment as a defense against these foreign encroachments. ${ }^{40}$

Social media co-option may thus blunt the reach of transnational social movements that use information linkages (including social media) to spread protest tactics and mobilize supporters abroad. This sort of regime-led protest inoculation is likely to be reinforced by the increasing territorialization of the internet. Moreover, the rapid spread of information through social media may benefit protestors, but its very agility can also promote the swift propagation of falsehoods or pro-regime 
narratives, especially if such discourse framing is backed by well-funded or technically proficient sources. Sidney Tarrow, for example, has argued that the internet has encouraged the rhetorical diffusion of a simplified version of Muslim ideology, "reducing the level of discourse to the lowest common denominator." 11

In sum, social media offers a number of ways to bolster regime legitimacy without the spectacle of manipulated elections. In doing so it offers an effective new channel for regime propaganda- a role that radio, newspapers, and television have all served in the past. Especially in the absence of a strong civil society, online media can function "as a particularly effective communication tool for state power." ${ }^{42}$ And because social media is inherently decentralized, interactive, and non-hierarchical, pro-regime discourse that takes place online can more easily avoid the appearance of artifice. In creating opportunities for regimes to connect with their supporters, it also presents a mechanism for controlling the boundaries of acceptable online debate, and does so in a way that doesn't merely block dissent but manipulates it to strengthen autocratic resilience.

\section{Revealing Mass Preferences}

Autocracies often exist in an information-scarce environment. This ignorance is partly self-induced by the mechanisms through which autocrats maintain their rule-the suppression of public dissent, the punishment of free expression, and the absence of institutional transparency. This paucity of information manifests itself in two related ways. First, autocracies have difficulties identifying the falsified private preferences of their citizens, and as a result may be unable to anticipate moments when silent miseries transform into vocal protests. ${ }^{43}$ Second, because local elites are politically unaccountable to their constituencies and operate through opaque institutions, central elites often lack sufficient information about their effectiveness and performance. The relationship between central and local elites in non-democratic states thus presents a classic case of a principal-agent problem: while central elites want to ensure compliance with their orders, local elites want to maximize the benefits they receive from their office while maintaining a facade of competence to their superiors. ${ }^{44}$

As scholars have noted, flawed elections can serve a useful function for autocrats by revealing information to the ruling regime about the strength and identity of both its supporters and its opponents. In the absence of free mass media or reliable opinion surveys, elections can reveal hidden preferences of both regime-friendly elites and the public at large. ${ }^{45}$ Such elections can "provide higher officials with helpful and otherwise concealed information on the operation of their subordinates, and pinpoint sensitive areas of public morale." ${ }^{46}$

While flawed elections can provide autocrats a glimpse of public preferences, social media offers a way to resolve informational asymmetries without the risk of electoral protest. ${ }^{47}$ First, it can act as continuous feedback loop between the rulers and the ruled, an informational mechanism through which elites can gain insights into hidden mass preferences and adjust policy accordingly. As Hu Jintao told the People's Daily in 2008, the internet "is an important channel for us to understand the concerns of the public and assemble the wisdom of the public." ${ }^{\prime 4}$ Second, reports of local corruption via social media give central elites more information about the effectiveness of local elites, offering a way to resolve the asymmetry of knowledge that characterizes the principal-agent problem discussed earlier. Internet technology, argues Xiao Qiang can "help to hold local officials more accountable - to the central authorities as well as to the public." ${ }^{\prime 9}$ In both cases, acting on public demands and cracking down on local corruption makes the regime appear more responsive, increasing its effectiveness and legitimacy.

Scholars of modern China have noted the increasing use of social media by the regime to gather information about public concerns. According to Qiang, Chinese party officials "are increasingly taking note and responding to public opinion as it expresses itself online." ${ }^{50}$ As Chinese internet expert Hu Yong has argued, "since China never had mechanisms to accurately detect and reflect public opinion, blogs and BBS have become an effective route to form and communicate such public opinions of the society." ${ }^{51}$ Rebecca MacKinnon contrasts classic authoritarianism with what she calls China's "networked authoritarianism" - a system in which "the single ruling party remains in control while a wide range of conversations about the country's problems nonetheless occurs on websites and social-networking services." ${ }^{\text {2 }}$ The government monitors these conversations and may even use them as a basis for changing unpopular and ineffective government policies. Thus the millions of messages circulated through Weibo act as "a de facto polling system that the state uses as a feedback mechanism to adapt its policies, inform official media or identify and neutralize potential threats. ${ }^{" 53}$ As a result, the average online citizen feels more free and the regime appears more responsive even as it retains its stranglehold on the country's political institutions. This sort of limited consultation enhances statesociety relations. The debates that take place through social media like microblogs, according to Nele Noesselt, "provide the party-state with more precise information about the general population's views, demands, and concerns." ${ }^{54}$

As a country with relatively few restrictions on online discourse, Russia has also been a beneficiary of information gleaned from social media. "Even in the absence of a truly free press," argues Evgeny Morozov, "Dmitry Medvedev can learn almost everything he needs from the diverse world of Russian blogs. ${ }^{55}$ In Russia as elsewhere, social media functions as an "early-warning system for the 
government, alerting policy makers when certain policies just are not working or need modification to prevent unrest." ${ }^{56}$ To facilitate the acquisition of this information, the regime has been developing online tools to aggregate citizen preferences. In April 2013 it launched the "Russian Public Initiative," an online petition platform that allows citizens to suggest policy changes at the federal, regional, and municipal level. If a policy gathers enough public support (in the form of votes by other registered users), the policy is then said to be reviewed by the appropriate legislative body. At the federal level, for example, an initiative that gathers 100,000 votes over the course of a year will then be discussed in the Duma. ${ }^{57}$ According to the pro-Kremlin mouthpiece Russia Behind the Headlines, "government ministries and agencies have put more effort into developing a presence online. The purpose of this increased online outreach is not only to keep Russians informed about government actions, but also to receive feedback and comments from citizens." ${ }^{58}$ Similarly, China now has an "e-parliament" website, which allows citizens to make policy suggestions on a variety of subjects "such as reducing local corruption, improving the environment, and proposing financial reforms."

Beyond government-run websites, information about public preferences is readily available from non-government Russian sources like VKontakte, Odnoklassniki, LiveJournal, as well from the Russian portions of Facebook, YouTube, and Twitter. Since the people active online tend to be better-educated and more politically involved than the average Russian citizen, ${ }^{60}$ tracking the shifting sentiments on these sites can yield a lot of information about pressing social concerns among those most likely to present a challenge to the regime. The surveillance of mass grievances does not even need to be highly sophisticated to be effective. For instance, simply being able to track sudden spikes in search terms on Russian search engines like Alexa can alert the regime to potential flashpoints.

The end result is a regime more attuned to the needs of its people, and one more willing to respond to those needs as long as they don't fundamentally threaten the regime's hold on power. As opposition leader Alexei Navalny said in a 2010 interview:

Actually, Internet for the government is some kind of a focus group. The Russian government is very populist. They just like to do what the people want. I mean, if it doesn't contradict their own interests. The political agenda, however, will be tested on the Internet. And that is why it will have an influence-but no direct impact. $^{61}$

Beyond acting as a cheap and reliable means of gauging public opinion, social media also offers a way for central authorities to keep track of local elites. These local officials may have strong incentives to filter the information they pass on to their bosses in a way that maximizes the perception of their effectiveness and ingratiates themselves with the central elites. In the absence of local accountability mechanisms found in democraciesunfettered mass media and local elections- these local elites can often operate in an environment of relative impunity, generating the potential for corruption and local discontent that undermines the legitimacy of the regime as a whole. ${ }^{62}$ This informational asymmetry may even encourage autocrats to create self-constraining institutions. Formal powersharing institutions, argue Carles Boix and Milan Svolik, regularize interactions between dictators and their agents and in doing so improve the transparency of decisionmaking, alleviating the monitoring problems inherent in non-democratic institutions. ${ }^{63}$

Establishing formal institutions to enhance monitoring, however, is sub-optimal if other mechanisms can fulfill these functions without constraining the ruling elite. Here, social media can act as a plausible substitute, a mechanism for coordinating elite interests between the central and local levels. In doing so it decreases informational asymmetries between the various layers of the regime's bureaucratic apparatus. As Qiang notes, one effect of microblogging in China is that "negative reports and criticism of local officials - especially relating to corruption, social justice, or people's daily experiencesare now being exposed and nationally disseminated online," a process encouraged by the Party as a way to "keep lower officials in check and to allow the public to let off steam." Given the enormous size and Byzantine structure of the Chinese government apparatus, onlinegenerated public opinion "is sometimes the sole channel for providing feedback to officials." ${ }^{\text {"4 }}$

Like China, Russia has encouraged citizens to report local problems that might otherwise escape their attention. This process is part of a more general trend in Russian politics over the past decade to centralize power in order to subdue local officials who were sometimes able to rule their regions with warlord-like autonomy in the 1990s. In 2012 the Kremlin announced plans to create its own Facebook-style social network. Created with private capital, the site would build upon an existing Medvedev-endorsed site, called "Russia Without Fools," which is designed to lodge complaints about public officials. Visitors to the site are encouraged to record any negative experiences with civil servants or government regulations, and this information is ostensibly to be used to sanction the offending officials or as a basis for changing ineffective or unpopular laws. ${ }^{65}$ "Anyone with a grudge against a local bureaucrat can leave a complaint as a comment on Medvedev's blog, a popular practice in Russia," writes Morozov. Regime officials subsequently "like to take highly publicized action in response to such complaints, replacing the crumbling infrastructure and firing the corrupt bureaucrats." 66 
The use of social media thus creates the potential for a low-level equilibrium trap: it does improve the range of possible discourse, allows people to call attention to social problems, gives them a greater sense of freedom, and may even result in concrete policy changes that improve their lives. According to The Economist:

Collective expression on the [Chinese] web, led by civic-minded microbloggers with millions of followers, is focusing attention on recurring problems ... That means the authorities now have to try to come up with credible responses to crises such as the huge spike in air pollution in January and February [2013]. In short, the internet requires the party centre to be more efficient at being authoritarian. ${ }^{67}$

However, the very same sense of government efficiency and accountability created by social media can make fundamental liberalizing reforms less likely in the long run. If citizens feel they have sufficient freedom to voice their grievances, and that the government is sufficiently responsive to such grievances, they may become less likely to call for radical reforms, and develop a sense of loyalty to the regime even in the absence of political pluralism. In this way limited reforms obviate the need for largescale transformation: the regime acts to eliminate local corruption and amends trivial but detested policies without loosening its hold on the monopoly of political power. The rigidity and lack of adaptability common in autocratic states is a persistent source of regime instability; to paraphrase John F. Kennedy, those who make incremental change impossible make fundamental change inevitable. By facilitating incremental change, social media can actually prolong the durability of non-democratic states while bolstering their popular legitimacy.

By acting as a barometer of public opinion, notes Qiang, social media "allows the government to collect information about society, to be more responsive to citizens' concerns, and to provide a safety valve for the release of public anger." ${ }^{68}$ This ability is crucial for nondemocratic regimes who may otherwise find themselves unprepared for upswells of anti-government sentiment. "If one assumes that authoritarian governments usually fall by surprise," Morozov notes, "then we also have to assume that, given how much data on the Internet can be harvested, analyzed, and investigated, surprises may become rarer." ${ }^{69}$

Social media cannot resolve all problems of preference falsification for incumbent governments. First, the socially mobile and educated citizens active in social media may not always be representative of public opinion at large, and may not reflect the preferences of rural constituencies or the poor. Yet it is precisely these qualities of social media participants-urban, young, and politically active-that make them a particularly important demographic for non-democratic regimes, and a key group in any potential outbreaks of protest. And as social media expands its reach beyond this demographic, governments may find it easier to extend pro-regime narratives to the population at large. Second, social media will not eliminate all preference falsification, since citizens may be afraid that even seemingly anonymous participation will result in prosecution. However, to the extent that social media increases the level of anonymous participation, it also encourages freer expression among those who previously preferred to censor their views. While social media cannot fully substitute for free expression as a mechanism of revealing public preferences, it may make the process of gathering such information easier for some regimes.

The lack of reliable information about the opinion of their citizens and the actions of their local agents has contributed to the downfall of many non-democratic regimes - a fact that rulers have not hesitated to recognize. ${ }^{70}$ Traditional closed regimes, however, have had limited options in rectifying these informational asymmetries and revealing falsified preferences, which may explain why autocrats have devoted so many resources to building networks of secret informants. The Chinese government has tolerated and even encouraged "routinized" small-scale protests precisely to identify potential grievances and resolve informational problems. ${ }^{71}$ Modern hybrid regimes, on the other hand, have a number of other tools at their disposal, including carefully managed political pluralism and manipulated elections. Social media adds yet another mechanism through which both closed and hybrid regimes can collect information about their people and local agents. Most importantly, it does so in a way that, unlike controlled protests or manipulated elections, does not so visibly endanger the regime's hold on power, making it an attractive substitute for some non-democratic incumbents.

\section{The Limits of Social Media Co-option}

Not every autocratic government is equally equipped to subvert social media for their own purposes, and such co-option possesses its own trade-offs and limitations. The Egyptian revolution, for instance, demonstrated how counter-mobilization by the government can occasionally backfire by antagonizing the protestors. According to $\mathrm{El}$ Hamamsy, "the government's attempts to sabotage the revolution came in the end to be used subversively by the protestors as means of resistance. It injected the revolution with more momentum, and in fact inadvertently led to its success." ${ }^{72}$ Similarly, the Ukrainian regime's attempts to identify and frighten protestors with ominous text messages in January 2014 only appeared to mobilize them further. $^{73}$

There are certain conditions, therefore, in which social media co-option is less likely to achieve its goals. Effective counter-mobilization, for example, requires the presence of clientelist networks or social groups whose members 
are willing to support the regime. Certain strategies of cooption are thus more likely to succeed in states with welldeveloped patronage networks, in which the interests of the ruling elite intertwine with the interest of powerful groups within the society at large.

Gathering information about mass preferences also requires a minimum level of technical competence and communications infrastructure - pre-requisites that weak or failing regimes may not possess. And discourse framing demands both sufficient public access to internet technology (which the poorest states may lack), and a minimum level of legitimacy among the public, who can accept and absorb these pro-regime narratives. Sarah Oates, for example, has argued that using social media to frame political narratives is less likely to succeed in states that have a strong civil society, whose members can attempt to counteract this rhetoric with their own. ${ }^{74}$

In short, social media co-option is not likely to aid non-democratic regimes that already lack legitimacy or institutional strength. As the cases of Egypt and Ukraine demonstrate, such co-option may also be less effective in times of crisis, when public opinion is both volatile and difficult to gauge properly. It appears more effective, on the other hand, in states lacking strong civil societies, during times of "normal" politics, and in regimes that possess some degree of functional institutionalization and popular legitimacy. If so, strong non-democracies (particularly hybrid regimes) may find social media to be a useful tool in maintaining their rule, while weak non-democracies may find it ineffective or even counter-productive.

\section{Conclusion: Social Media and the Future of Democracy}

Non-democratic regimes have only recently begun to realize the full potential of co-opting social media for their own purposes. This trend, therefore, is likely to intensify in the near future, with profound consequences for the future of democratization and state-society relations. Government involvement in internet technology has continuously evolved from early strategies of brute-force denial to more sophisticated strategies of control and contestation. ${ }^{75}$ Here I have focused on the latest phase of this evolution-what I call the shift from contestation to co-optation. This strategy incorporates elements of censorship and control, but also builds on them to actively subvert the reach and power of online technology in order to strengthen the regime's grip on political life.

The shift from contestation to co-optation is reinforced by two other developments - the increased territorialization of the internet, and the diffusion of autocratic best practices. The web is increasingly becoming less of a public common good and more of a reflection of national borders. Russia's Runet has its own popular blogs, search engines, e-mail services and social network sites that remain largely isolated from the global web. Similarly, China has its own set of Chinese-language online resources that operate within the Great Firewall and rarely interact with the larger online world. A number of countries like Iran and Kazakhstan are developing their own national "cyberzones" as a substitute for Western alternatives. The fragmentation of the internet serves the interests of many powerful actors - countries can use them to strengthen their grip over content and access, while corporations can use them to take control over their intellectual property. They may even appeal to consumers, "since access to them is less costly and the resources that can be found there are almost exclusively in the local language."76

Regime co-option of social media is also facilitated by the diffusion of best practices among autocrats. According to Morozov, one key feature of modern cyberspace is "how much and how quickly authoritarian governments seem to learn from each other." 77 For example, Syria has borrowed Iran's expertise in online surveillance and internet filtering to track and identify opposition members. $^{78}$ And countries such as Saudi Arabia and Vietnam have brought in Chinese internet specialists to show them more effective ways of blocking Western websites. ${ }^{79}$ Thus according to MacKinnon, "regimes seeking to control and stifle dissent have been learning quickly from one another as well as from China." ${ }^{80}$ The pace of autocratic adaptation is only likely to accelerate in the near future, as regimes increasingly learn from the mistakes and successes of their peers, and share the tactics and technologies used to subvert social media.

In the long run, therefore, the assumption that increased access to information will overturn autocratic regimes may be unjustified. "The authoritarian state is inherently fragile and will quickly collapse if information flows freely," wrote the sociologist Ithiel de Sola Pool. ${ }^{81}$ Yet autocrats have proven to be remarkably adaptive and resilient in the face of new challenges. Even the harshest dictators have an incentive to allow some degree of social media freedom - enough to gauge public opinion but not so much that discussion spills over into protest. ${ }^{82}$

Autocracies therefore possess an optimal threshold level of social media freedom, always above zero but never approaching the level of unfettered discourse. Consequently, evidence of online debate is not necessarily a sign of regime weakness but a harbinger of its durability. And while social media may make regimes more responsive at the local level, it also produces a shallow sort of democracy, one in which populist causes like municipal corruption are taken up by the central government, sometimes with great fanfare, even as the chances of fundamental reform like multi-party competition become more remote.

Most importantly, social media may decrease the incentives for hybrid and autocratic regimes to hold elections in order to reveal hidden information and bolster regime legitimacy. Hybrid regimes may thus 
become more likely to get rid of elections altogether, while closed autocracies will become less likely to introduce them. Increasingly, social media offers a "safer" alternative to unfair elections-a non-electoral substitute for shaping public discourse, forging ties with regime supporters, revealing hidden public preferences, and coordinating elite interests. Unlike simple censorship, these strategies strengthen the regime rather than merely mitigate the effects of dissent. The subversion of social media by autocracies and hybrid regimes may thus increase the durability of non-democratic regimes at the cost of long-term prospects for democratization.

\section{Notes}

1 See Gandhi and Lust-Okar 2009 for an overview.

2 Acemoglu and Robinson 2006; Howard, Agarwal, and Hussain 2011.

3 Hyde and Marinov 2012.

4 For example, according to Gehlbach 2012, signs of electoral fraud in Russia's 2012 election are found at the level of returns from local voting precincts.

5 Yang 2009.

6 Deibert and Rohozinski 2010, 36.

7 Shirky 2009, Howard 2010, Diamond 2010.

8 Deibert et al. 2008, 2010, 2011.

9 Alterman 2011, Gladwell 2010, Morozov 2011 a.

10 Shirky 2011.

11 Lynch 2011:302.

12 For an early and in some ways prescient exception, see Boas and Kalithi 2003. As they noted, "authoritarian regimes can guide the development of the Internet so that it serves state-defined goals and priorities"; Boas and Kalithi 2003, 136.

13 Oates 2013, 7.

14 Aday et al. 2010, 20.

15 Greitens 2013, 263.

16 Blaydes 2011; Brownlee 2011; Gill 2010, 306; Simpser 2013; Zaslavsky and Brym 1978, 369.

17 Quoted in Amos 2012.

18 Zheng 2008.

19 King, Pan, and Roberts 2013.

20 Hassid 2012.

21 Schmidt and Cohen 2013.

22 Greitens 2010, 268.

23 Ibid.

24 Deibert and Rohozinski 2011, 27.

25 Polyanskaya, Krivov, and Lomko 2003.

26 Tumanov 2012.

27 Elder 2012.

28 Smirnov et al. 2012; Newsru.com 2012.

29 Garmazhapova 2013.

30 Deibert and Rohozinski 2011, 16.

31 MacKinnon 2012, xxii.

32 Kononov 2014.
33 Fossato and Lloyd 2008, 53.

34 Bandurski 2008.

35 Deibert et al. 2011, 13.

36 Greitens 2013, 265.

37 MacKinnon 2012, 64-65.

38 Al-Jazzera English 2011. See also Rundle 2011.

39 MacKinnon 2012, 62.

40 Koesel and Bunce 2013, 759.

41 Tarrow 2010, 210.

42 Oates 2013, 101.

43 Kuran 1991.

44 As Egorov and Sonin 2011 note, the trade-off between loyalty and competence is a persistent problem in nondemocratic regimes, limiting rulers' access to unpleasant but vital information.

45 Magaloni 2006.

46 Swearer 1961, 143-4.

47 As Malesky and Schuler $(2011,491)$ point out, in using elections as a mechanism for revealing preferences, "authoritarians face a trade-off between gathering reliable information and guaranteeing electoral victory."

48 Quoted in MacKinnon 2012, 43.

49 Qiang 2011, 47.

50 Ibid.

51 Quoted in Qiang 2011, 56. On China's “authoritarian deliberation"- a process in which competing arguments and policy activism are allowed to exist within certain state-controlled limits, see $\mathrm{He} 2006$, He and Warren 2011, and Jiang 2010.

52 MacKinnon 2011, 33.

53 Sullivan 2014, 8.

54 Noesselt 2014, 450. Similarly, Lorentzen 2014 argues that certain kinds of Chinese media liberalization can help the regime by exposing local corruption and reducing discontent.

55 Morozov 2011a, 92.

56 MacKinnon 2012, 71.

57 Russian Public Initiative 2013.

58 Russia behind the Headlines 2011.

59 MacKinnon 2012, 42.

60 Fossato and Lloyd 2008.

61 Quoted in Asmolov 2010.

62 Geddes 2006, Gehlbach and Keefer 2010.

63 Boix and Svolik 2013.

64 Qiang 2011, 56.

65 Vesti.ru 2012.

66 Morozov 2011a, 92.

67 Economist 2013, 5.

68 Qiang 2011, 59.

69 Morozov 2011a, 165.

70 Louis XIV once described "the art of governing" as "knowing everything that people try to conceal from us, their secrets, and keeping close watch over them." Quoted in Kuran 1991, 30. 
71 On the use of routinized protests as an informationgathering mechanism, see Lorentzen 2013 and Chen 2012.

72 Hamamsy 2011, 454.

73 Walker 2014.

74 Oates 2013, 101.

75 Deibert et al. 2011.

76 Deibert and Rohozinski 2010, 28.

77 Morozov 2011a, 139.

78 Reporters without Borders 2013.

79 Kurlantzick 2010.

80 MacKinnon 2012, 53.

81 de Sola Pool 1973.

82 I thank Ron Deibert for this formulation.

\section{References}

Acemoglu, Daron, and James Robinson. 2006. "Economic Backwardness in Political Perspective." American Political Science Review 100(1): 115-131.

Aday, Sean, Henry Farrell, Marc Lynch, John Sides, John Kelly, and Ethan Zuckerman. 2010. "Blogs and Bullets: New Media in Contentious Politics." United States Institute of Peace. Report No.65. www.usip.org/sites/ default/files/pw65.pdf

Alterman, Jon B. 2011. "The Revolution Will Not Be Tweeted." Washington Quarterly 34(4): 103-16.

Amos, Howard. 2012. "From Russia with Likes: Kremlin to Launch Facebook-style Social Network." The Guardian, June 19. http://bit.ly/1jlw6Nt, accessed October 23, 2013.

Asmolov, Gregory. 2010. "Russia: Blogger Navalny Tries to Prove That Fighting Regime Is Fun." Global Voices Online, October 27. http://bit.ly/1dWihUG, accessed November 26, 2013.

Bandurski, David. 2008. "China's Guerilla War for the Web." Far Eastern Economic Review 171(6): 41-44.

Blaydes, Lisa. 2011. Elections and Distributive Politics in Mubarak's Egypt. Cambridge: Cambridge University Press.

Boix, Carles, and Milan W. Svolik. 2013. "The Foundations of Limited Authoritarian Government: Institutions, Commitment, and Power-Sharing in Dictatorships." Journal of Politics 75(2): 300-16.

Brownlee, Jason. 2011. "Executive Elections in the Arab World: When and How Do They Matter?" Comparative Political Studies 44(7): 807-28.

Bunce, Valerie J., and Sharon L Wolchik. 2011. Defeating Authoritarian Leaders in Post-communist Countries. Cambridge: Cambridge University Press.

Chen, Xi. 2012. Social Protest and Contentious Authoritarianism in China. New York: Cambridge University Press.

Deibert, Ronald J., John G. Palfrey, Rafal Rohozinski and Jonathan Zittrain, eds. 2008. Access Denied: The Practice and Policy of Global Internet Filtering. Cambridge, MA: MIT Press.
2010. Access Controlled: The Shaping of Power, Rights, and Rule in Cyberspace. Cambridge, MA: MIT Press.

- 2011. Access Contested: Security, Identity and Resistance in Asian Cyberspace. Cambridge, MA: MIT Press.

Deibert, Ronald J., and Rafal Rohozinski. 2010. "Control and Subversion in Russian Cyberspace." In Access Controlled: The Shaping of Power, Rights, and Rule in Cyberspace, ed. Ronald J. Deibert, John G. Palfrey, Rafal Rohozinski and Jonathan Zittrain. Cambridge, MA: MIT Press.

Diamond, Larry. 2010. "Liberation Technology." Journal of Democracy 21(3): 69-83.

Economist. 2013. "A Giant Cage." (Special Report: China and the Internet) April 6, p.3-5. http://econ.st/ 18Xt5hw, accessed August 13, 2013.

Egorov, Georgy, and Konstantin Sonin. 2011. "Dictators and Their Viziers: Endogenizing the Loyalty-Competence Trade-Off." Journal of the European Economic Association 9(5): 903-30.

Elder, Miriam. 2012. "Hacked Emails Allege Russian Youth Group Nashi Playing Bloggers." The Guardian, February 7. http://bit.ly/1hWpRV5, accessed November 21, 2013.

Farrell, Henry. 2012. "The Consequences of the Internet for Politics." Annual Review of Political Science 15: $35-52$.

Fossato, Floriana, and John Lloyd, with Alexander Verkhovsky. 2008. "The Web That Failed: How Opposition Politics and Independent Initiatives Are Failing on the Internet in Russia." Reuters Institute for the Study of Journalism Report. http://bit.ly/17VPhIO, accessed November 13, 2013.

Gandhi, Jennifer, and Ellen Lust-Okar. 2009. "Elections under Authoritarianism." Annual Review of Political Science 12: 403-22.

Garmazhapova, Aleksandra. 2013. "Gde zhivut trolli [Where the trolls live]." Novaya Gazeta, September 9, 2013. http://bit.ly/1cbOpSY, accessed November 26, 2013.

Geddes, Barbara. 2005. "Why Parties and Elections in Authoritarian Regimes." Presented at the annual meeting of the American Political Science Association, Washington, DC, September 1-4.

Gehlbach, Scott, and Philip Keefer. 2010. "Private Investment and the Institutionalization of Collective Action in Autocracies: Ruling Parties and Legislatures." Working Paper. University of Wisconsin-Madison and the World Bank Development Research Group. http:// ssrn.com/abstract $=1663057$

Gehlbach, Scott. 2012. "Electoral Fraud in Russia: Report from the Russian Blogosphere." The Monkey Cage, January 27. http://bit.ly/1bJElyK, accessed November 28, 2013. 
Gill, Graeme. 2010. "Elections." In The Encyclopedia of Communism, ed. Silvio Pons and Robert Service.

Princeton, NJ: Princeton University Press.

Gladwell, Malcolm. 2010. "Small Change: Why the Revolution Will Not Be Tweeted." The New Yorker, October 4, 42-49. http://nyr.kr/1aNoS2X, accessed September 17, 2013.

Greitens, Sheena Chestnut. 2013. "Authoritarianism Online: What Can We Learn from Internet Data in Nondemocracies?" PS: Political Science and Politics 46(2): 262-70.

Hamamsy, Walid El. 2011. "BB=Blackberry or Big Brother: Digital Media and the Egyptian Revolution." Journal of Postcolonial Writing 47(4): 454-66.

Hassid, Jonathan. 2012. "Safety Valve or Pressure Cooker? Blogs in Chinese Political Life." Journal of Communication 62(2): 212-30.

He, Baogang, and Mark E. Warren. 2011. "Authoritarian Deliberation: The Deliberative Turn in Chinese Political Development." Perspectives on Politics 9(2): 269-89.

Herron, Erik S. 2011. "Measuring Dissent in Electoral Authoritarian Societies: Lessons from Azerbaijan's 2008 Presidential Election and 2009 Referendum." Comparative Political Studies 44(11): 1557-83.

Howard, Philip N. 2010. The Digital Origins of Dictatorship and Democracy: Information Technology and Political Islam. New York: Oxford University Press.

Howard, Philip N., Sheetal D. Agarwal, and Muzammil M. Hussain. 2011. "The Dictators' Digital Dilemma: When Do States Disconnect Their Digital Networks?" Issues in Technology Innovation 13, Brookings Center. http://bit.ly/Ilw5x7, accessed November 25, 2013.

Hyde, Susan D., and Nikolay Marinov. 2012. "Which Elections Can Be Lost?” Political Analysis 20: 191-210.

Jiang, Min. 2010. "Authoritarian Deliberation on Chinese Internet." Electronic Journal of Communication 20(3/4). http://ssrn.com/abstract $=1439354$, accessed November 20, 2013.

King, Gary, Jennifer Pan, and Margaret E. Roberts. 2013. "How Censorship in China Allows Government Criticism but Silences Collective Expression.” American Political Science Review 107(2): 1-18.

Koesel, Karrie J., and Valerie J. Bunce. 2013. "DiffusionProofing: Russian and Chinese Responses to Waves of Popular Mobilizations against Authoritarian Rulers." Perspectives on Politics 11(3): 753-68.

Kononov, Nickolay. 2014. "The Kremlin's Social Media Takeover." New York Times, March 14. http://nyti.ms/ 1qt42Oy, accessed June 19, 2014.

Kuran, Timur. 1991. "Now Out of Never: The Element of Surprise in the East European Revolution of 1989." World Politics 44(1): 7-48.

Kurlantzick, Joshua. 2010. "The Web Doesn't Spread Freedom.” Newsweek, May 9. http://bit.ly/17Qiw4O, accessed November 2, 2013.
Lorentzen, Peter L. 2013. "Regularizing Rioting: Permitting Public Protest in an Authoritarian Regime." Quarterly Journal of Political Science 8: 127-158. . 2014. "China’s Strategic Censorship." American Journal of Political Science 58(2):4012-14.

Lynch, Marc. 2011. "After Egypt: The Limits and Promise of Online Challenges to the Authoritarian Arab State." Perspectives on Politics 9(2): 301-10.

. 2013. "Twitter Devolutions: How Social Media Is Hurting the Arab Spring." Foreignpolicy.com, February 7. http://atfp.co/1i2KTRM, accessed November 15, 2013.

MacKinnon, Rebecca. 2011. "China's 'Networked Authoritarianism'.” Journal of Democracy 22(2):32-46. . 2012. Consent of the Networked: The Worldwide Struggle for Internet Freedom. New York: Basic Books. Magaloni, Beatriz. 2006. Voting for Autocracy: Hegemonic Party Survival and Its Demise in Mexico. New York: Cambridge University Press.

Malesky, Edmund, and Paul Schuler. 2011. "The Single-Party Dictator's Dilemma: Information in Elections without Opposition." Legislative Studies Quarterly 36(4): 491-530.

Morozov, Evgeny. 2011a. The Net Delusion: The Dark Side of Internet Freedom. New York: PublicAffairs Books.

. 2011b. "Whither Internet Control?" Journal of Democracy 22(2): 6274.

Newsru.com. 2012. "Varlamov otvetil na obvineniya v bloge [Varlamov responds to accusations on his blog]." February 7. http://bit.ly/1jtNsIf, accessed November 20, 2013.

Noesselt, Nele. 2014. "Microblogs and the Adaptation of the Chinese Party-State's Governance Strategy." Governance 27(3): 449-68.

Oates, Sarah. 2013. Revolution Stalled: The Political Limits of the Internet in the Post-Soviet Sphere. New York: Oxford University Press.

Peterson, Andrea. 2014. "Ukraine's 1984 Moment: Government Using Cellphones to Track Protestors." Washington Post, January 21. http://wapo.st/KAiDqU, accessed January 21, 2014.

Polyanskaya, Anna, Andrei Krivov, and Ivan Lomko. 2003. "Virtualnoye Oko Stareshevo Brata [The Virtual Eye of Big Brother]." Vestnik Online 9(320), April 30. http://bit.ly/1cItVkH, accessed November 20, 2013).

Qiang, Xiao. 2011. "The Battle for the Chinese Internet." Journal of Democracy 22(2): 47-61.

Reporters without Borders. 2013. "Syria." March 12. http:// bit.ly/1bZ7N7m, accessed November 7, 2013.

Rundle, Michael. 2011. "How Bahrain's 'Facebook Uprising' Allowed Authorities to Target Protestors." Huffington Post, April 8. http://huff.to/1jtP04U, accessed September 21, 2013. 
Russia behind the Headlines. 2011. "Russian Government Becomes More Accessible Online.” March 24, 2011. http://bit.ly/1aOoKjI, accessed November 4, 2013.

Russian Public Initiative. 2013. http://bit.ly/17Q1eEZ, accessed November 17, 2013.

Schmidt, Eric, and Jared Cohen. 2013. "The Dark Side of the Digital Revolution." Wall Street Journal, April 19. http://on.wsj.com/1h82QwZ, accessed November 24, 2013.

Shirky, Clay. 2009. Here Comes Everybody: The Power of Organizing Without Organizations. New York: Penguin. . 2011. "The Political Power of Social Media: Technology, the Public Sphere, and Political Change." Foreign Affairs 90(1). http://fam.ag/1jBPc4b, accessed June 18, 2014.

Simpser, Alberto. 2013. Why Governments and Parties Manipulate Elections: Theory, Practice and Implications. New York: Cambridge University Press.

Smirnov, Sergei, Aleksander Artemyev, Svetlana Boncharova, Grogoriy Tumanov. 2012. "Zachem ya vyol Zh-Zh, esli za nego niche go ne poluchu? [Why did I blog on LiveJournal if I get nothing out of it?].” Gazeta.ru, February 6, 2012. http://bit.ly/19PsG03, accessed November 20, 2013.

Pool, Sola, Ithiel de. 1973. "Communication in Totalitarian Societies." In Handbook of Communication, ed. Ithiel de Sola Pool, Frederick W. Frey, Wilbur Schramm, Nathan Maccoby, Edwin B. Parker. Chicago, IL: Rand McNally.

Sullivan, Jonathan. 2014. "China's Weibo: Is Faster Different?" New Media \& Society 16(1): 24-37.
Swearer, Howard H. 1961. "The Functions of Soviet Local Elections." Midwest Journal of Political Science 5(2): 129-49.

Tarrow, Sidney. 2010. "Dynamics of Diffusion: Mechanisms, Institutions, and Scale Shift." In The Diffusion of Social Movements: Actors, Mechanisms, and Political Effects, ed. Rebecca Kollins Givan, Kenneth M. Roberts, and Sarah A. Soule. New York: Cambridge University Press. Tumanov, Grigory. 2012. "Pervoye intervyu rossiskikh Anonymous, vzlomavshikh pochtu glavy Rosmoldyozhi Vasilia Yakemenko [First interview with AnonymousRussia, who had hacked into the e-mail of youth group leader Vasily Yakemenko]." Gazeta.ru, February 6. http://bit.ly/1iCnTqH, accessed November 20, 2013.

Vesti.ru. 2012. "Sayt 'Rossiya bez durakov' nachal prinimat' zhaloby na chnovnichnye gluposti [Site 'Russia without fools' has begun to take complaints about officials' nonsense]." January 23. http://bit.ly/I9TfY5, accessed November 14, 2013.

Walker, Shaun. 2014. "Text Messages Warn Ukraine Protestors They Are 'Participants in Mass Riot'." The Guardian, January 21. http://bit.ly/1ikeV2Z, accessed June 19, 2014.

Yang, Guobin. 2009. The Power of the Internet in China: Citizen Activism Online. New York: Columbia University Press.

Zaslavsky, Victor, and Robert J. Brym. 1978. "The Functions of Elections in the USSR." Soviet Studies 30(3): 362-71.

Zheng, Yongnian. 2008. Technological Empowerment: The Internet, State, and Society in China. Stanford, CA: Stanford University Press. 